\title{
ACHIEVING NET-ZERO STATUS WHILE EMPHASIZING THE HERITAGE ARCHITECTURE LANDMARK OF THE ORGAN PIPE CACTUS NATIONAL MONUMENT IN ARIZONA, USA
}

\author{
NADER CHALFOUN \\ College of Architecture, University of Arizona, USA
}

\begin{abstract}
The House Energy Doctor program at the University of Arizona is aimed at advanced understanding of the theory and principles related to sustainability in green building design, energy conservation, and passive solar high-performance buildings. Faculty and students of the program are currently engaged in a multi-year effort towards accomplishing a vision and a goal that would preserve the heritage of the Organ Pipe Cactus National Monument buildings while transforming its status into a world-class first net-zero park in the nation. The project is a collaboration with a team of experts in heritage architecture from the park. During the first fiscal year of 2015, three major tasks have been accomplished that include the development of seven net-zero design schemes for the visitor center using energy performance simulation and analysis and the integration of advanced environmental systems. To achieve these goals, 3 courses, 7 faculty members, and over 32 students collaborated on the work through first, an advanced integrative environmental design and research studio that focuses on regional sustainable energy efficient high performance buildings and emphasizes on latest environmental technologies for indoor and outdoor spaces. The studio investigated the heritage conservation aspects of the visitor center pertinent to Mission 66 standards. Second, a House Energy Doctor course that provides service while fostering hands-on inquiry based learning. Buildings' energy conservation and passive solar design were investigated through up-to-date computer energy simulation techniques and Level III energy audits and field investigation of the buildings. And, third, a luminous, thermal, and acoustic laboratory-based course where theoretical learning is verified by empirical research and experimentation. Many of the technologies that were prescribed to buildings on the Organ Pipe Cactus National Monument campus were tested in the laboratory. This paper demonstrates the methods used during the first year and illustrates the findings and results of the research.
\end{abstract}

Keywords: net-zero, national park, energy efficiency, solar, cool towers.

\section{INTRODUCTION}

The Organ Pipe Cactus National Monument extends its geographical borders from southwestern Arizona down south to Sonora, Sinaloa and Baja California in Mexico. The name of this National Monument comes from the Organ Pipe cactus plant, which can be only found in this part of the world. The park is a showcase that celebrates the life and landscape of the Sonoran Desert and its many wilderness of plants, animals, dramatic mountains and unique desert scenery converge within 500 square miles.

The House Energy Doctor "Design and Energy Conservation" program at The University of Arizona's College of Architecture, Planning, and Landscape Architecture (CAPLA), directed by Professor Chalfoun, has been in contact with the park superintendent to initiate a 3-year effort to conduct Level III Energy Audits and develop an energy plan that will achieve a sustainable net zero energy compatible campus with minimum carbon footprint that will become a showcase for all other park services in the United States. 


\section{ACHIEVING NET-ZERO STATUS FOR THE PARK}

The goal is to identify the Park's buildings energy performance and consumption and through design and simulation develop energy efficiency improvement opportunities that will achieve net-zero status and reduce carbon footprint for all four park built areas (Fig. 1). These are, the Visitor Center (includes Administrative offices, bookstore, museum displays, projection/media room, and Visitor Information Center), the Housing Areas (an administration building with 9 residential units, 2 attached duplex facilities, and two resource centers), the Maintenance, Resources, and Law Enforcement Facility (a series of attached maintenance labs arranged in two parallel blocks and three adjacent manufactured office trailers one of which is used by Law Enforcement Rangers, the Campgrounds (208 space campground with RV sites up to $40 \mathrm{ft}$, and a designated tent section., six restrooms).

During the first year of the agreement, in 2015, three major tasks have been accomplished by the House Energy Doctor's students and faculty. These activities that included: 1) development of seven design schemes for the visitor center through studio 601 ; 2) three residential energy analysis through 561d; and 3) several environmental experiments and tests were conducted at the Environmental Research Laboratory of the House Energy Doctor Program to verify the performance of proposed energy efficient strategies through 561p.

\subsection{Region Studio 601}

The studio is an advanced integrative environmental design and research platform that focuses on regional sustainable energy efficient high performance buildings emphasizing latest environmental technologies for indoor and outdoor spaces. The project focused on developing the Kris Eggle Visitor Center (Fig. 2).
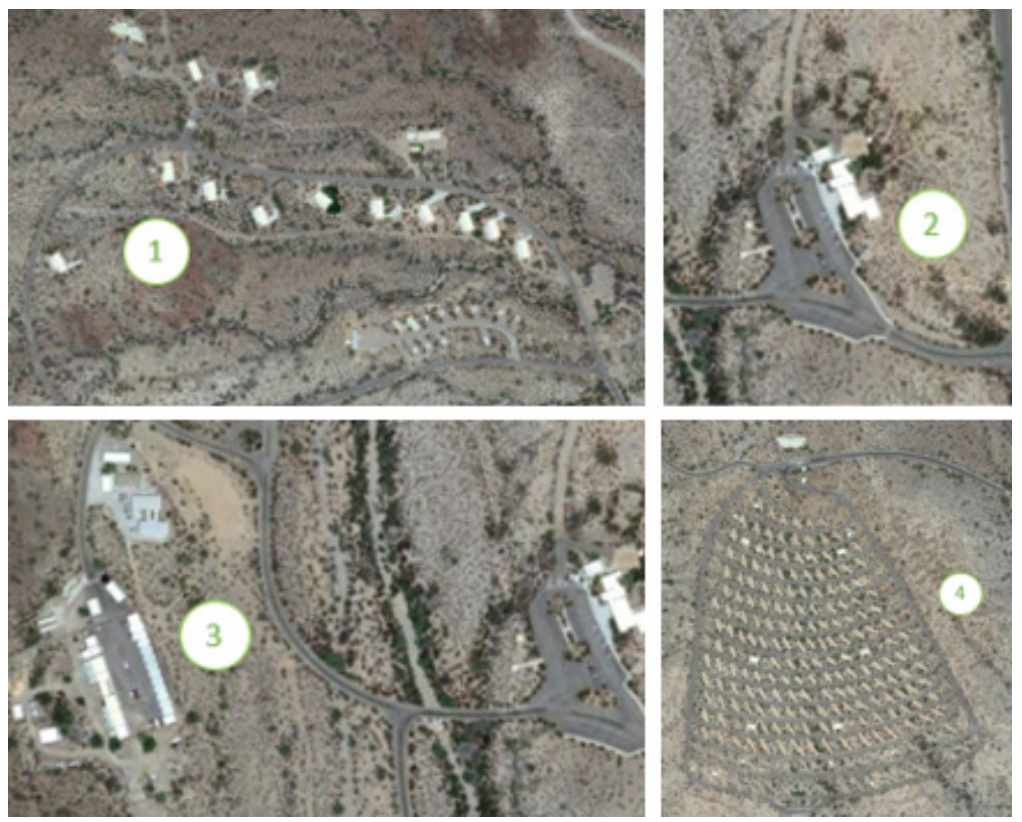

Figure 1: The four built areas at Organ Pipe Cactus National Monument. 


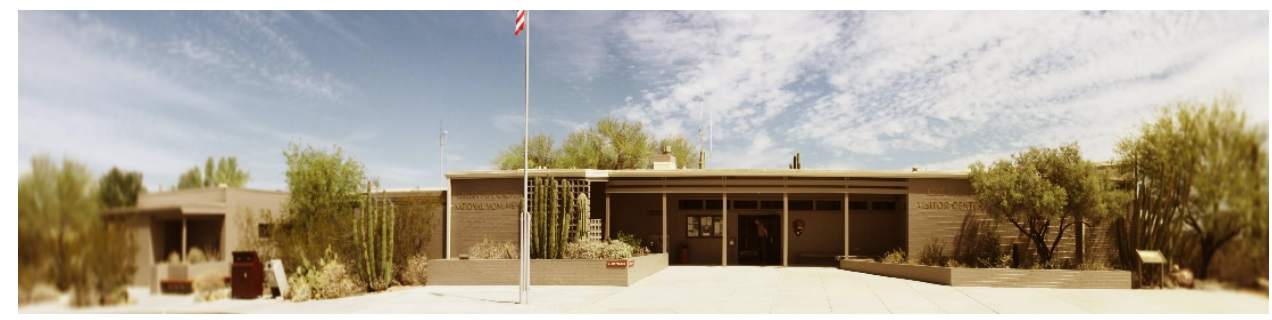

Figure 2: Kris Eggle Visitor Center at the Organ Pipe Cactus National Monument.

After two visits to the park by the studio faculty and students, design and climatic analysis have been conducted to verify some of the current building deficiencies and a summary of observations has been developed. Some of the observed deficiencies dealt with building's orientation, uninsulated CMU of the envelope, lack of shading, lack of connectivity between the building and its surroundings, un-emphasized building entrance with drop off area, minimum use of passive and active strategies such as natural ventilation, daylight, rainwater harvesting, or renewable energy, and insufficient potential pre-planned activities for visitors to interact with the building. Analysis of these deficiencies resulted in student development of seven alternative design schemes. All themes suggested state-of-the art methods and technologies that would transform the current visitor center into a world-renowned energy efficient net-zero facility. The schemes names were: 1) Nature, Visitor, and Building; 2) Shading Tinajas; 3) The Journey from Ground to Stars; 4) Endless Desert; 5) Gates of Knowledge; 6) The Desert Undercover; and 7) A Journey Through Shade.

\subsubsection{Theme 1: "Nature, Visitor, and Building"}

This theme design philosophy is based on redefining the visitor center's relationship between nature, visitor, and building, integrating these three elements through the use of sight, feeling and sound. Enhancing the visitor experience, encouraging further exploration of the unique yet beautiful surrounding of the Sonoran Desert (Fig. 3).

\subsubsection{Theme 2: "Shading Tinajas" (Spanish for large earthenware jar)}

This theme design philosophy states: "Life in the Sonoran Desert is dependent on two critical elements; that are responsible for shaping the environment. Shade and Water." Design efforts focused on creating a roof geometry that is inspired by the surrounding mountains that is using the concept of collecting water (Figs 4 and 5).

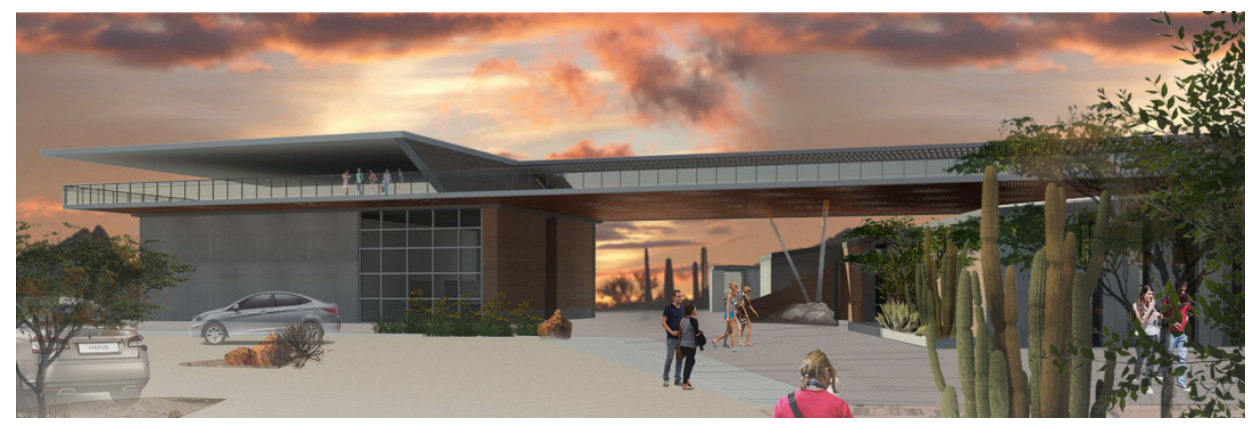

Figure 3: Site plan and rendering of the "Nature, Visitor, and Building" design scheme. 

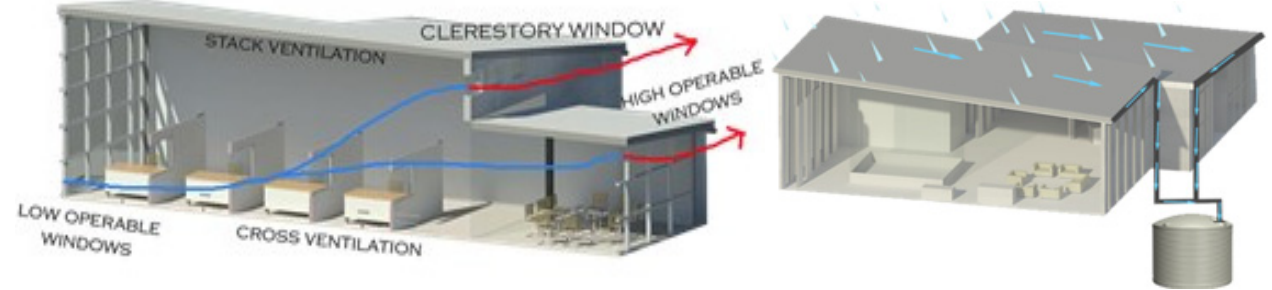

Figure 4: Diagrams of the natural ventilation and rain water collection strategies.
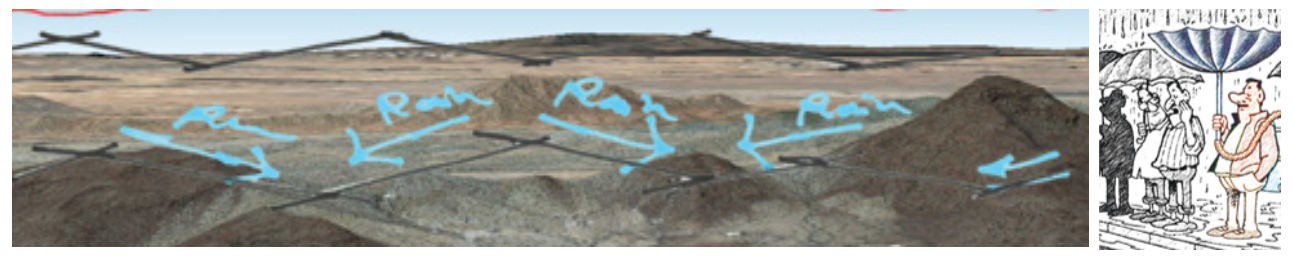

Figure 5: Concept of Shading Tinajas.

In addition to creating a water collection roof geometry, the double roof acted as a shading device cutting the intense direct solar radiation and reducing the external surface Sol-Air temperature by three times. The roof also integrates cool towers to cool the external spaces through evaporative cooling, solar tubes to enhance the use of daylight, and PV arrays (Fig. 6).

\subsubsection{Theme 3: "Journey from Ground to Stars"}

The main goal of this project is to achieve a sustainable building which can primarily reduce energy consumption and generate the amount of energy needed for operation through renewable clean energy (Fig. 7). The emphasis is on fully understanding the process through a thorough environmental analysis that will help achieve this goal. Education of the building users and care of architectural aesthetics and articulation that maintain the architecture heritage also played a major role in development of this scheme.

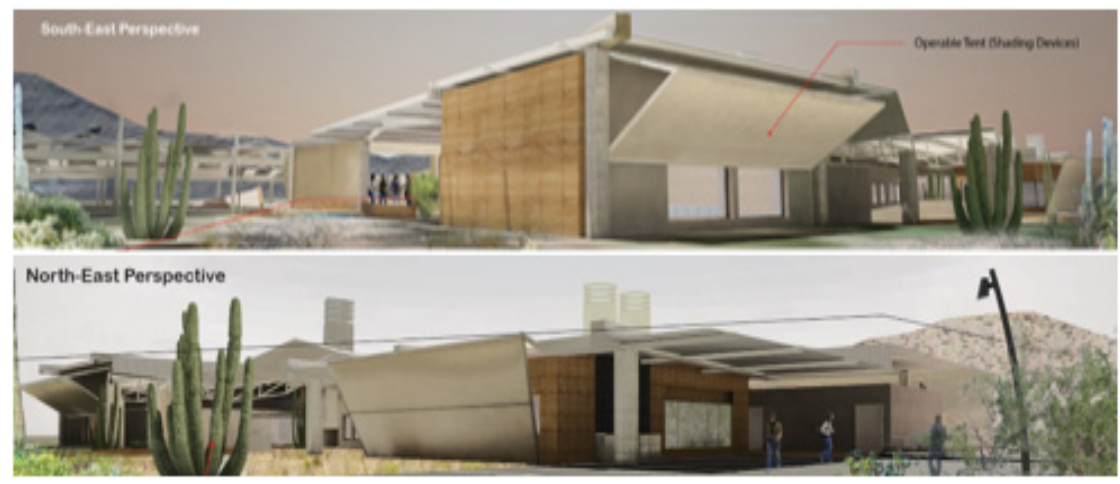

Figure 6: Design development of "Shading Tinajas Scheme". The double roof integrated solar tubes that provided day lit areas at the center of building. 


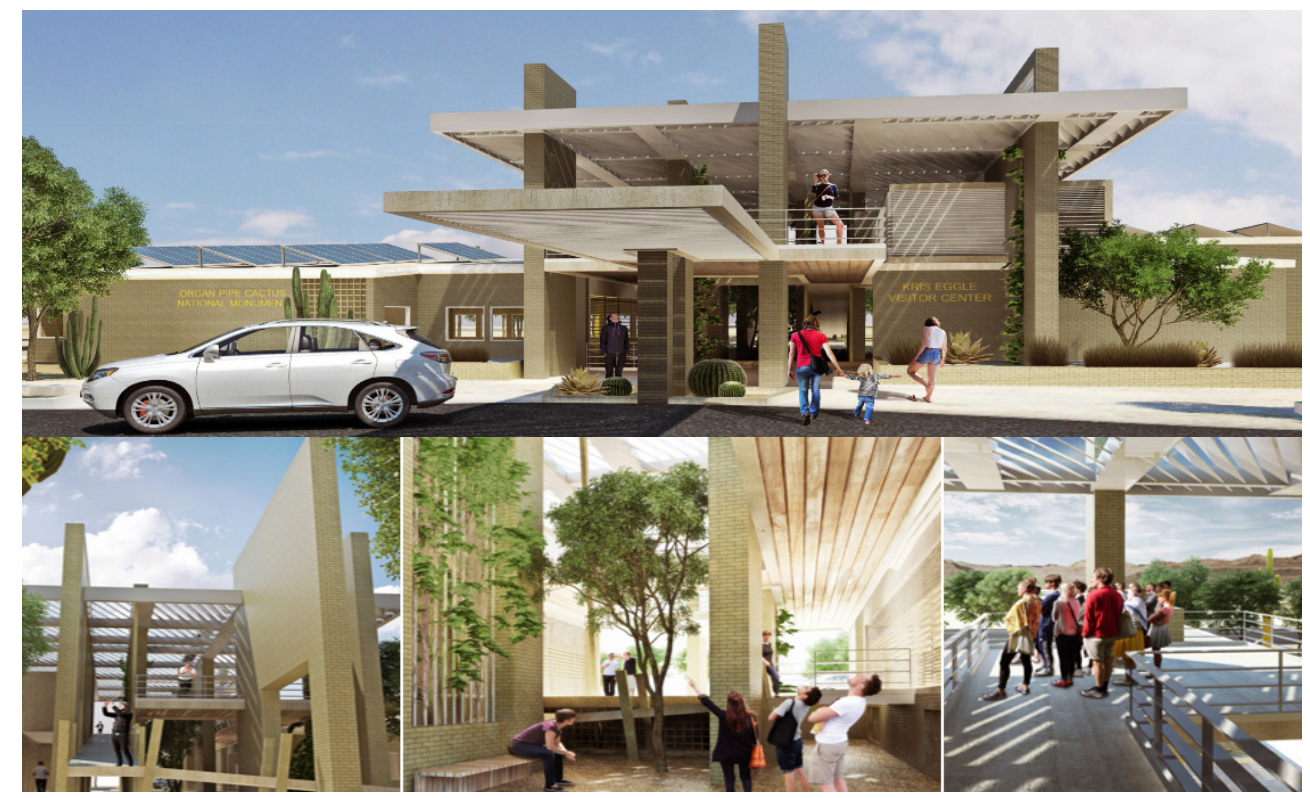

Figure 7: The east-west expanding thermal mass walls created a thermal environment by which the absorbed heat is released to the sky through the perforated shading roof.

\subsubsection{Theme 4: "Endless Desert"}

The main goal of this project is to focus on the outdoor experience. Visitors should feel comfortable as they relax and soak in the endless desert views, feel the fresh desert winds, and enjoy that middle-of-nowhere silence. The design intension is to create a building with less boundaries that has a comfortable outdoor and indoor space experience, and introduces as much view of the park as possible (Figs 8 and 9).

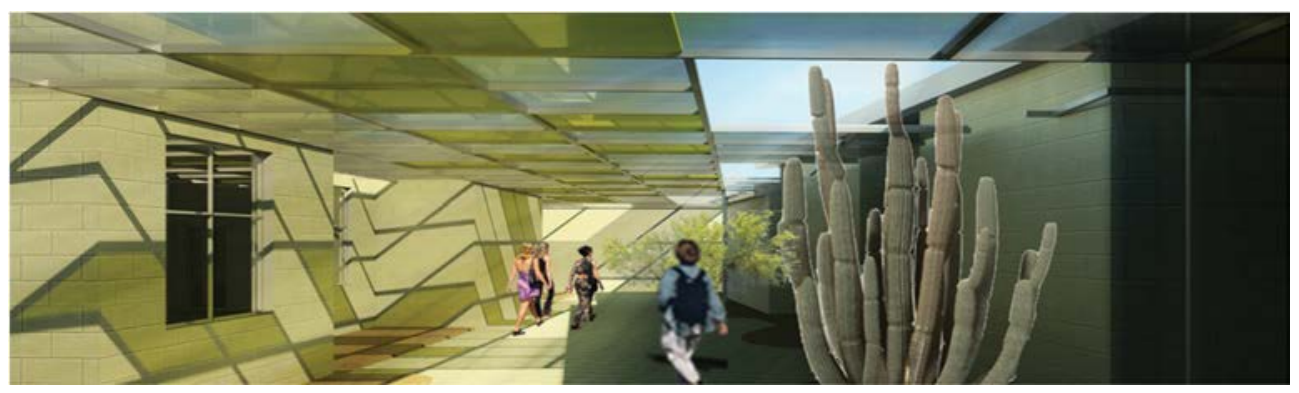

Figure 8: Connectivity between the indoors and outdoors. 

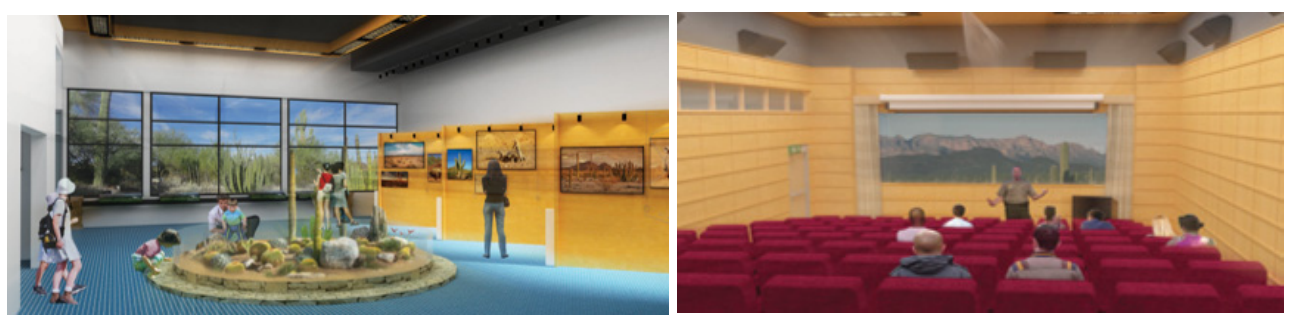

Figure 9: All spaces have large, shaded, strategically placed windows to the outside.

\subsubsection{Theme 5: "Gates of Knowledge"}

This design scheme recognizes that the Organ Pipe Cactus National Monument is the top destination in the southwest for indoor and outdoor activities because of the indigenous specious and nature. It attempts to emphasis this notion through a series of so-called gates of knowledge. These nodes introduce education opportunities for visitor to experience fist-hand and learn about desert living in a thermally comfort environment demonstrating state-of-the-art energy efficiency and passive solar strategies (Figs 10 and 11).
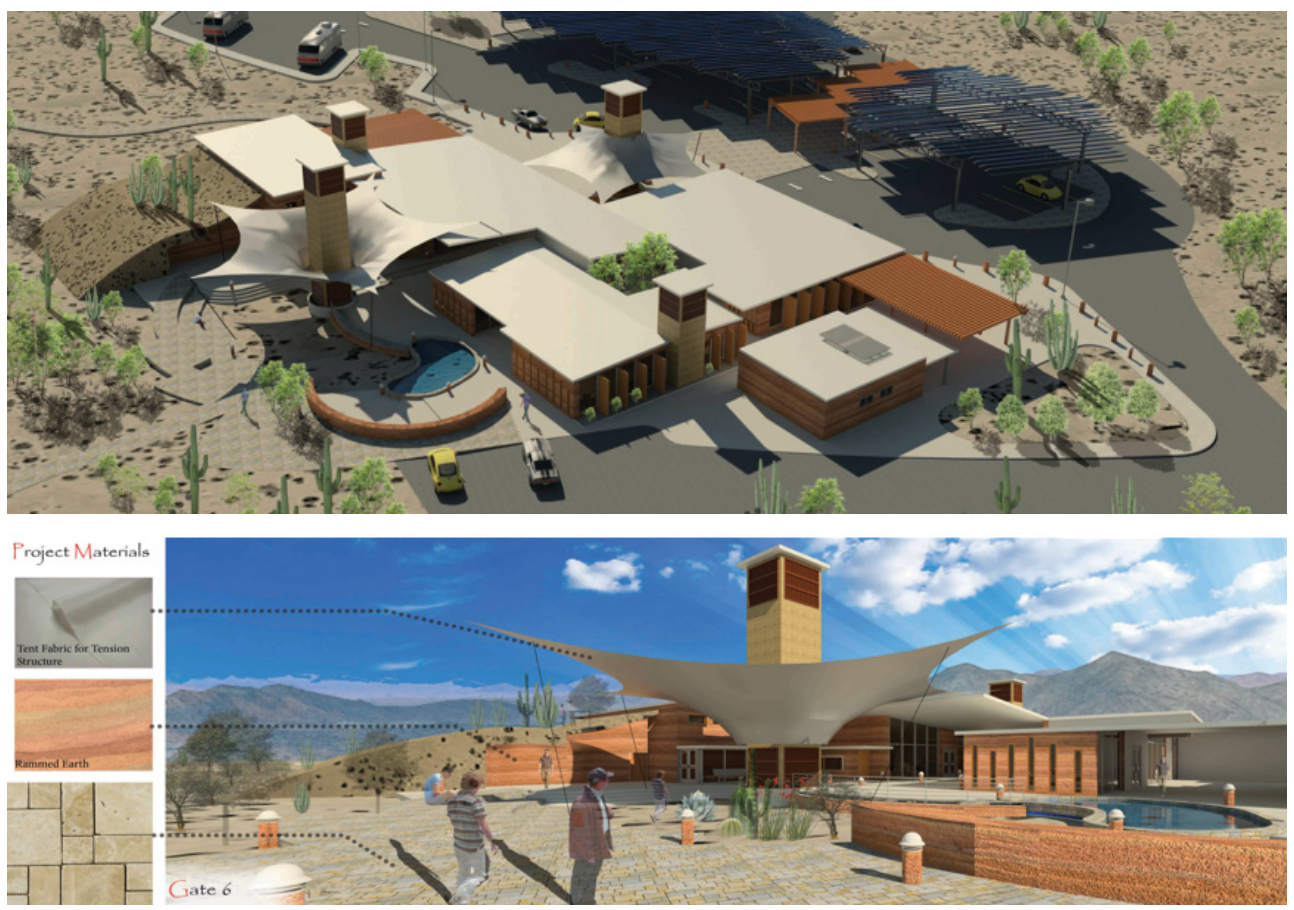

Figure 10: The use of cool towers creates identity to the different gates of knowledge while the associated shading tensile structures act as rain water harvesting devices. 


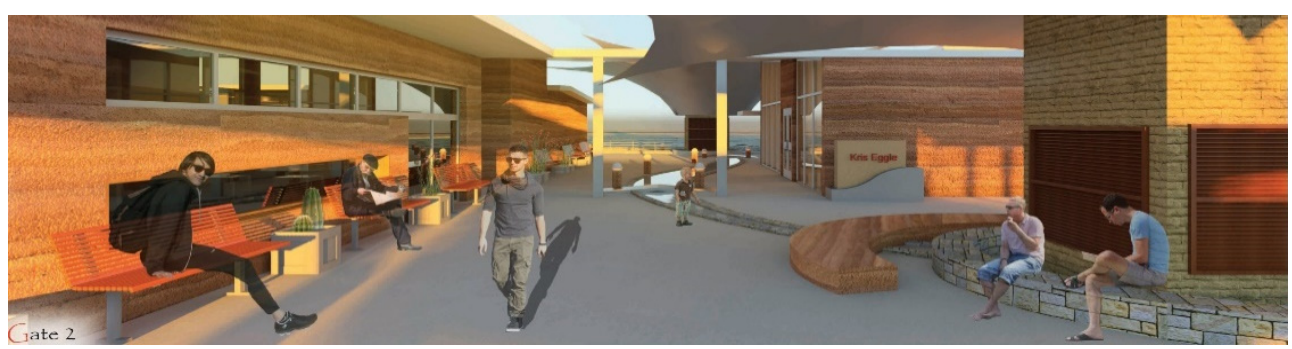

Figure 11: Thermal comfort outdoors encourages visitor's interaction and learning.

\subsubsection{Theme 6: "The desert Undercover"}

The main goal of this design theme is to emphasize on the fact that shade, movement, and views of the surrounding Sonoran Desert are primary driving factors for the Desert Under Cover. These concepts will create a more inviting, comfortable, and educational experience within the re-designed Kris Eggle Visitor Center (Fig. 12).

\subsubsection{Theme 7: "A Journey through Shade"}

The big idea of this theme is focused on a design that incorporates different cooling effects, based on shading and natural ventilation, while still allowing for the connection through the site (Fig. 13). The visitor center will offer interactive tools that will engage the visitors and teach them about the principles of shading, among other environmental strategies that are crucial in the desert (Fig. 14).

\subsection{House Energy Doctor Level III Energy Audits 561d}

The House Energy Doctor program provides service while fostering hands-on inquiry based learning. The 561d course teaches energy conservation and passive solar architecture design through up-to-date computer energy simulation techniques and applied Level III energy audits and field investigation of existing or new buildings. Three residential units \#28, \#37, and \#47 at the Organ Pipe Cactus Park has been analyzed and their energy performance have been optimized through advanced energy efficiency strategies. On average, all building saved about $50 \%$ of the current operational energy usage. Renewable energy strategies applied to the residences to convert them to net-zero operation.
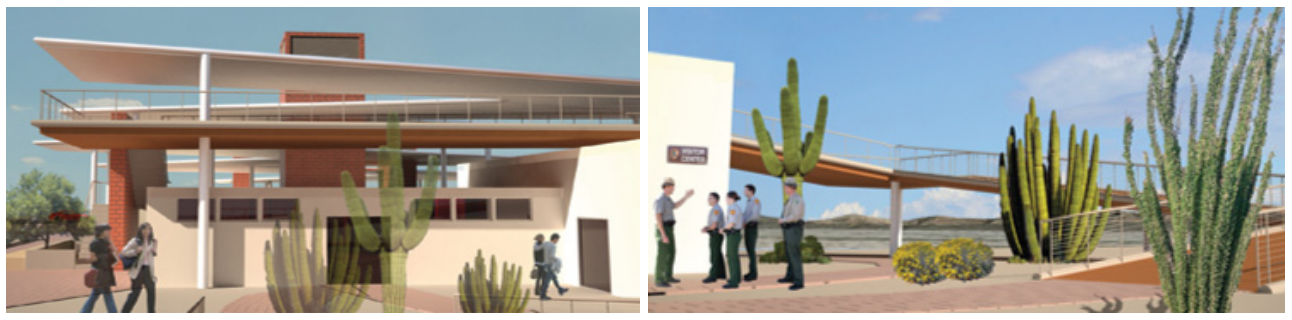

Figure 12: A series of ramps designed to facilitate movement of the visitors to strategic viewing points. While acting as shading devices at times, they integrate a number of cool towers and they harvest energy from the sun through thin-film PV floors. 

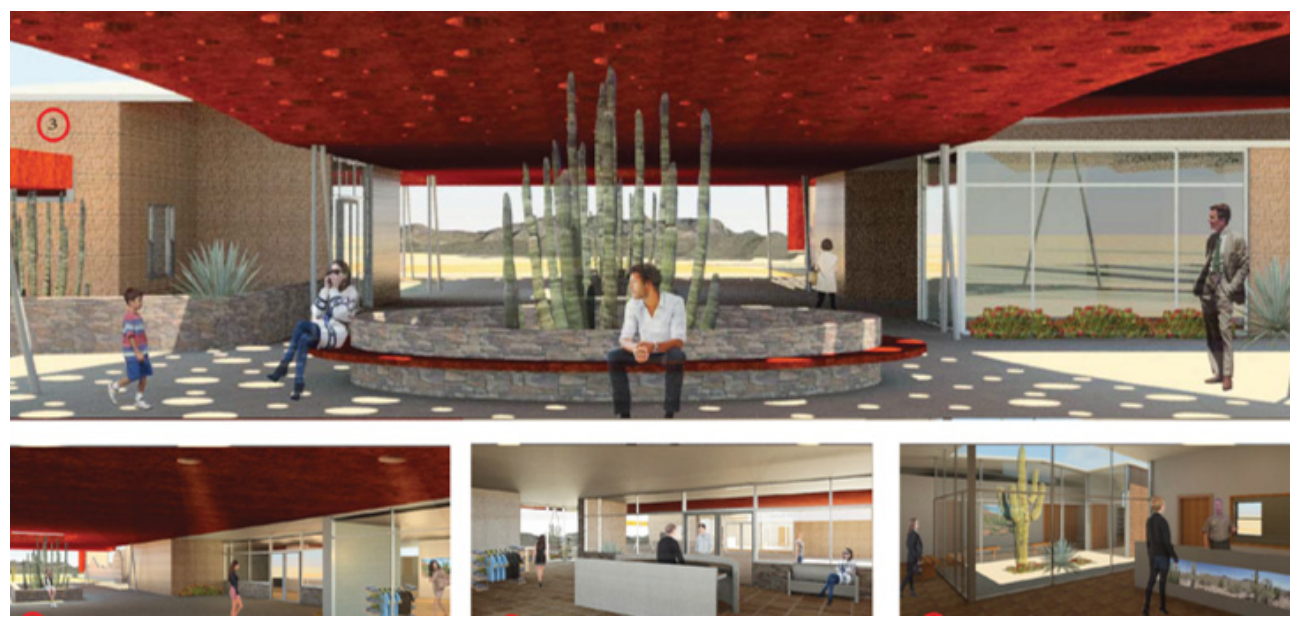

Figure 13: The east-west expanding thermal mass walls created a thermal environment by which the absorbed heat is released to the sky through the perforated shading roof and creates a thermal chimney that draws cooler air from the cool surrounding landscapes.
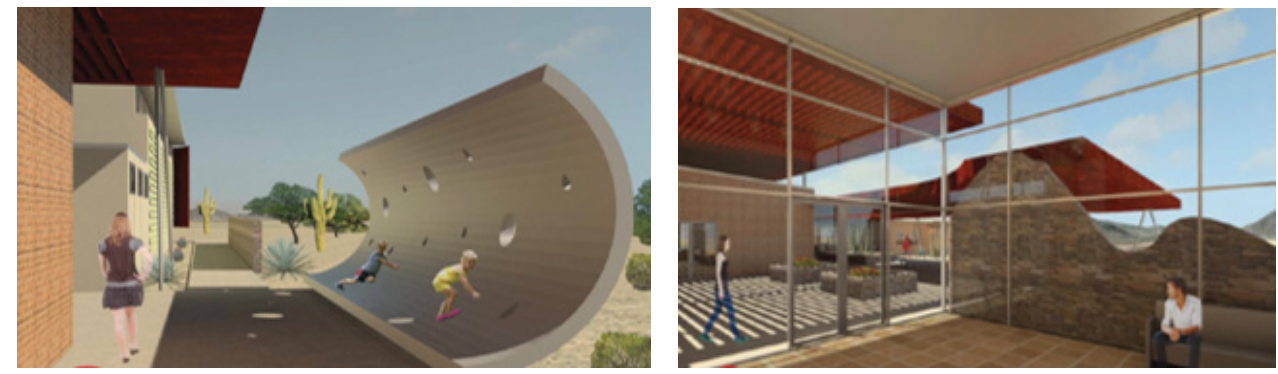

Figure 14: Shade is provided through exterior and interior strategies enhancing the user's experience with the desert.

\subsubsection{Pre-Audit Phase}

In order to assure successful energy audits important information must be obtained and processed in advance. The information will then be used while conducting the actual audit and do inspection and measurements. The time for this preparation process, identified as a Pre-Audit Phase and requires the followings:

- Obtain construction documents of each building

- Equipment/mechanical system specifications including and hours of operation

- Utilities information and bills from the previous three years

- Users and building occupancy schedule

- Development of site forms specific to each building

- Coordination of visits date/time with building owners/managers

- Compilation of all the above into a Pre-Audit report to be handed to the students 


\subsubsection{Level III Energy Audit Phase}

Students and faculty visit the site of buildings and use specific instruments and tools to conduct a level III energy audit (Fig. 15). A specially designed site forms are also used to document the information in greater detail and to make sure all data needed by the computer simulation engine is collected.

After the site visit and energy audit students investigate and predict the thermal performance of the building using two different software; E-10 for residential construction and eQUEST for commercial buildings. All buildings must first be verified for their code compliance using the REScheck ${ }^{\mathrm{TM}}$ and COMcheck ${ }^{\mathrm{TM}}$ software. Results of the as-is and code compliance case are documented to estimate the current energy consumption and cost of operation of the buildings.

\subsubsection{Parametric analysis and pre-net-zero status}

Following Base Case performance prediction, parametric analysis is conducted by student's teams to optimize the performance of buildings and to verify and estimate the energy and cost savings resulting from each energy efficiency strategy including its carbon reduction and return on investment (Fig. 16).

\subsubsection{Guidelines for heritage conservation of National Register of Historic Places}

President Franklin Roosevelt designated the Organ Pipe Cactus Park as a National Monument on April 13, 1937. All onsite buildings been designated on the National Register of Historic Buildings. The energy and solar retrofit strategies that are proposed by the design team must be in compliance with the "Illustrated Guidelines for Rehabilitating Historic Buildings" published in 1992. The National Park Service Branch of Technical Preservation Services has developed these illustrated guidelines in accordance with its directive to provide information concerning professional methods and techniques to ensure the preservation and rehabilitation of the historic properties that are an important part of the nation's heritage.
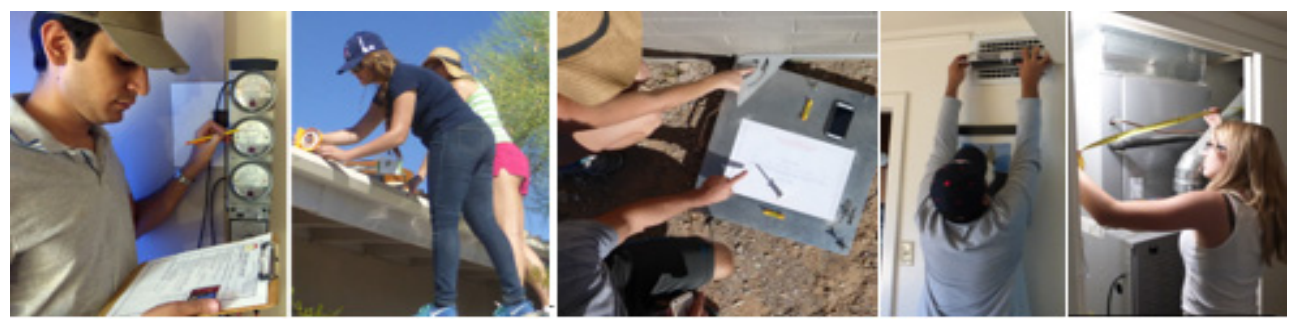

Figure 15: House Energy Doctor@ students conducting Level III energy audit.

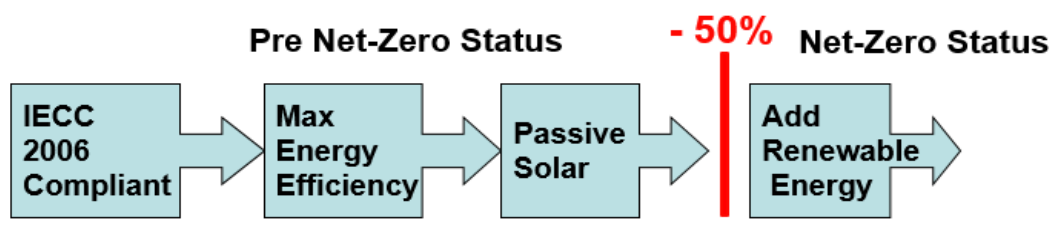

Figure 16: House Energy Doctor® net-zero approach for residential, commercial, and multi-family buildings. 
The House Energy Doctor design team consulted the Secretary of the Interior's Standards for Rehabilitation to come up with a list of recommended or acceptable energy efficiency and solar strategies to be used on existing buildings that will help convert the Park's operation to net-zero. These strategies are:

- Add green roof: must consider water sealing, not visible from public access road, structurally sound, uses native plants)

- Use solar cells: must consider minimum visibility, cause no damage to existing roof, low profile, Tesla new technology)

- Use wind energy: must validate feasibility as it need minimum $12 \mathrm{mph}$ annual average wind, cause no damage

- Use of daylight: add door, windows, and high windows to corridors, use light well or solar tubes, must consider controls

- Site development: use of shade trees, permeable paving, replace impermeable surfaces, use of native plants, add bio swales, rain gardens, rain barrels, rainwater collection tanks and cisterns)

- HVAC: replace with High Efficiency (SEER) rating, programmable thermostat, use of split systems, add flex and exposed ducts, use ceiling fans, use of geothermal exchange heat pumps.

- Insulation: add to unfinished spaces, add air tightening weather-stripping.

- Add windows: in corridors and as Trombe walls with low-emissivity coating.

2.2.5 Energy simulation and results

After conducting the parametric analysis and apply energy conservation strategies, results were documented and presented to park authority with explanation of each strategy and details on implementation, cost, and energy savings.

To illustrate some of the results, House\#47 on the residential loop have been analyzed and energy saving strategies has been applied. Analysis demonstrate a total $51.95 \%$ savings, a typical task to achieve the pre-net-zero status (Figs 17 and 18).
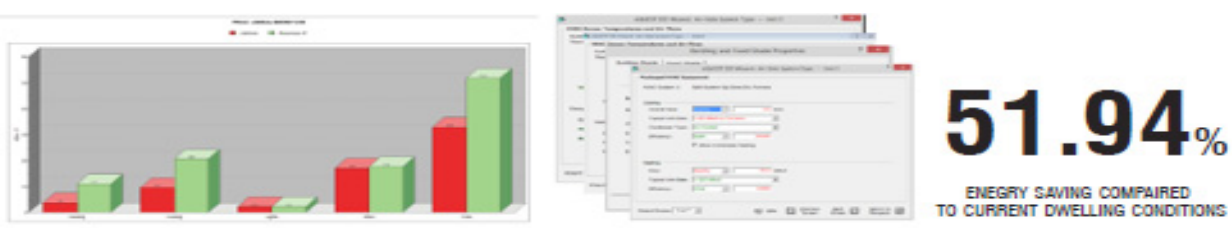

ENEGRY SAMNG COMPAIFED TO CURRENT DWEUING CONDITIONS

Figure 17: Computer energy simulation results showing the predicted performance improvement due to energy conservation and passive solar strategies.

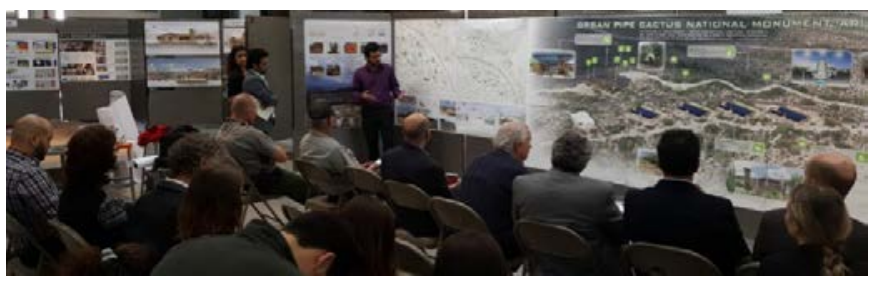

Figure 18: Final presentations of proposed retrofit designs and energy conservation and solar strategies that achieve the net-zero status. 


\subsection{Environmental science laboratory testing and verifications}

A House Energy Doctor luminous, thermal, and acoustic laboratory where Theoretical learning is verified by empirical research and experimentation. The Laboratories includes a 28 -feet-long boundary layer contractionless wind tunnel, the only and largest in the southwest, an outdoor thermal comfort advanced data acquisition instrumentation with state-of-the-art sensor technology. And an Artificial Uniform Overcast Sky Simulator apparatus (1200-foot candle) is used for daylight testing and photometric measurements in physical models. Several environmental analyses and tests have been done on the Organ Pipe Cactus National Park project including testing daylight and stack, cross, and displacement ventilations for the newly designed spaces of the visitor center (Fig. 19).

\section{CONCLUSION}

Faculty and students of the House Energy Doctor program engaged in a multi-year effort towards accomplishing a vision and a goal that would preserve the heritage of the Organ Pipe Cactus National Monument buildings while transforming its status into a World-Class first net-zero park in the nation. During the first fiscal year of 2015, three major tasks have been accomplished that include the development of seven net-zero design schemes for the visitor center using energy performance simulation and analysis and the integration of advanced environmental systems. To achieve these goals, 3 courses, 7 faculty members, and over 32 students collaborated on the work through first, an advanced integrative environmental design and research studio that focuses on regional sustainable energy efficient high performance buildings and emphasizes on latest environmental technologies for indoor and outdoor spaces. The studio investigated the heritage conservation aspects of the visitor center pertinent to Mission 66 standards. While the studio presented 7 different schemes to achieve net-zero status for the visitor center, the energy analysis of three residences on the park demonstrated an average 50\% energy consumption reduction. This was the goal to achieve the net-zero status. In the coming two years, more residences will be analyzed and more designs will be introduced until the net-zero status of the park is achieved.
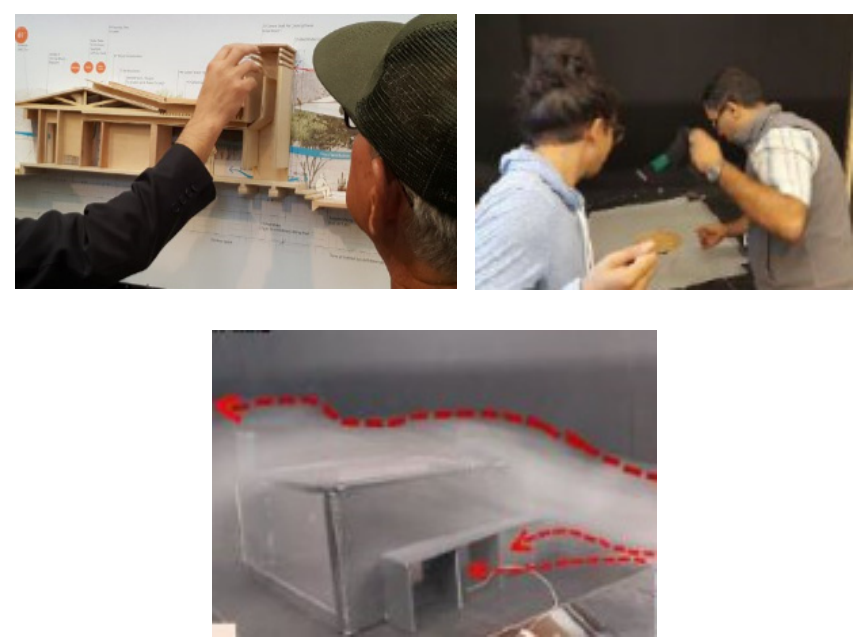

Figure 19: Students conducting daylight analysis using the Overcast Sky Simulator and natural ventilation tests using the Boundary layer wind tunnel at the House Energy Doctor's environmental science laboratory. 


\section{ACKNOWLEDGEMENTS}

The author would like to acknowledge Brent Range, Superintendent, Rijk Moräwe, Chief of Natural \& Cultural Resources Management, Bob Bryant, Facility \& Energy Manager, and Katy Northcutt, Admin Support Tech. at the Organ Pipe Cactus National Monument for their efforts in coordinating this project and hosting the team during their visits to the park. Professors Colby Moeller and Ray Barnes for their collaboration on the project, Assistant Professor Omar Magdy and Ivan Gaxiola, as well as all the students who conducted the design and research for the first year.

\section{REFERENCES}

[1] Balcomb, D., ENERGY-10 User's Manual, 2000.

[2] Chalfoun, N.V., House Energy Doctor's Level III Building Energy Audits as pedagogy and outreach. American Solar Energy Society ASES and International Solar Energy Society ISES, National Solar Conference, San Francisco, CA, 10 Jul. 2016.

[3] Chalfoun, N.V., A method for greening university campus buildings while fostering hands-on inquiry-based students' learning. 6th International Multi-Conference on Engineering and Technological Innovation, IMETI, Orlando, FL, 9-12 Jul. 2013 .

[4] Spiric, L., Al-Hashim, A. \& Chalfoun, N.V., Net Zero station design for The Cooper Centre for the Environmental Learning in Tucson, Arizona. BESS-SB13 CALIFORNIA: Advancing Towards Net Zero, Pomona, CA, 24-25 Jun. 2013.

[5] Chalfoun, N.V., et al., Cool towers: Integrate passive cooling for buildings and spaces in the arid southwest. ASES National Solar Conference, Phoenix, AZ, 17-22 May 2010.

[6] Chalfoun, N., The "House Energy Doctor $\odot$; an educational, research and community service program at the College of Architecture, The University of Arizona. Proceedings of the Design for Desert Living Symposium, Tucson, AZ, 21-26 Jul. 1991.

[7] Chalfoun, N. \& Michal, R., Thermal performance comparison of alternative building envelope systems: Analysis of five residences in the community of Civano. Architectural Research Centers Consortium (ARCC), College of Architecture and Environmental Design, ASU, Phoenix, AZ, 10-12 Apr. 2003.

[8] Hirch, J.J., DOE-eQUEST User's Manual, 2003. 